\section{Planning Brings Vision Into Focus}

\section{DOE Office of Indian Energy On-the-Ground Technical Assistance Helps Tribes Chart a Path Toward Clean Energy Success}

Many Tribes have established visions related to community energy. In order to move energy projects and initiatives forward, Tribes need a long-term strategy and a clear path to reach their goals.

The U.S. Department of Energy (DOE) Office of Indian Energy Policy and Programs (Office of Indian Energy) provides Tribes and Alaska Native entities with technical and financial assistance to encourage, facilitate, and assist in energy and energy infrastructure development on tribal lands.

"Ideas and data are nothing but pictures and words on a page without the action needed to bring them to life," said DOE Office of Indian Energy Director Tracey LeBeau. "Ultimately it is the people - committed tribal leaders and staffs and determined community energy champions - who make it all happen. DOE's role is to help sharpen their vision while providing the tools, training, and expertise needed to break down the barriers and provide a path forward."

The Office of Indian Energy established the Strategic Technical Assistance Response Team (START) Program to empower tribal leaders to advance clean energy projects in their communities. START works with select Tribes to implement a strategic energy planning process that provides a step-by-step road map to success.

By following the steps outlined in the process, Tribes bring their desired energy future into clearer focus and document a game plan for short- and long-term achievements. This can provide valuable guidance for addressing energy challenges in times when tough decisions need to be made amid the fallout from tightening budgets, natural disasters, or political administration changes.

"Strategic energy planning creates an opportunity for Tribes to engage their communities, staff, and stakeholders in a process to define energy development as a catalyst for growth and to establish a vision and actionable strategies the community can pursue," said Alexander Dane, START team member and project leader at the National Renewable Energy Laboratory (NREL).

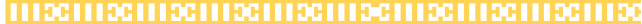

\section{Benefits of Strategic Energy Planning}

- Cost savings for community members

- Potential revenue from renewable energy generation

- A stronger economy

- Greater energy independence and security

- Local influence over energy facility siting

- More efficient communities

- Healthier communities

- A cleaner environment

- Regional tribal coordination and collaboration

- A chance to demonstrate leadership.

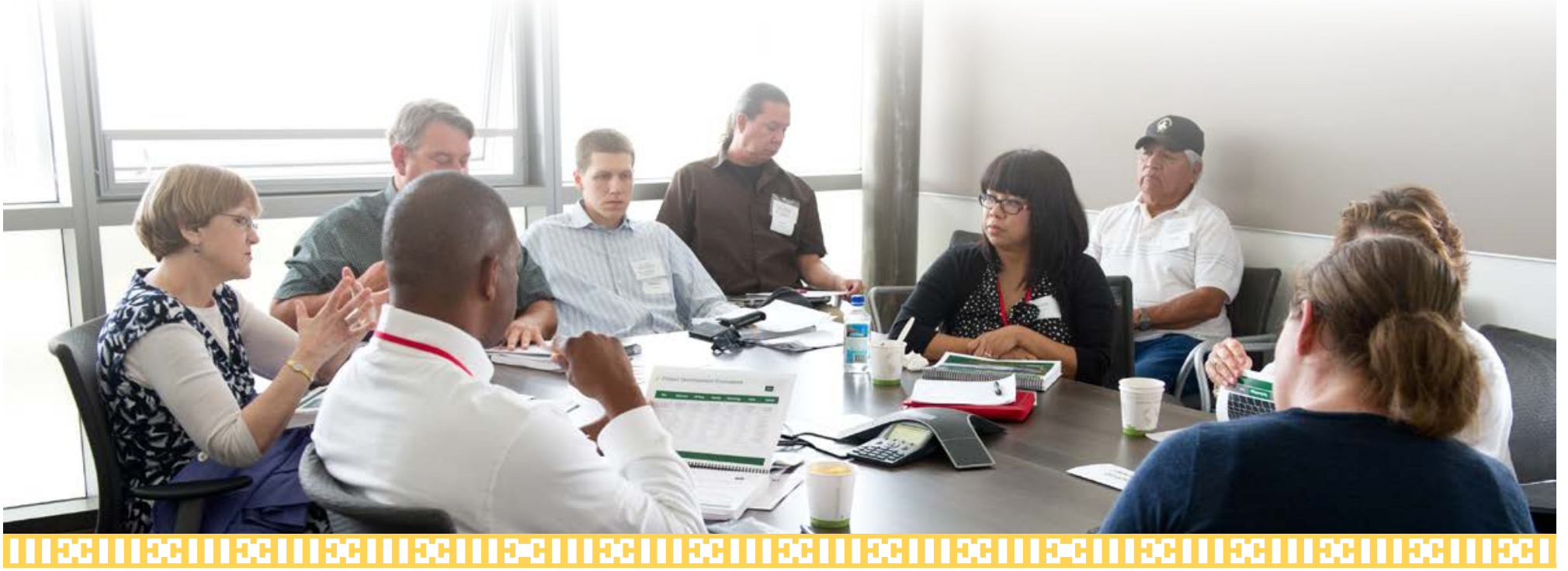




\section{Importance of Strategic Energy Planning}

Tribal energy development can stimulate opportunities that serve all of the sectors of the Tribe if it is inclusive in the planning stages. Strategic community energy planning is critical to a Tribe's future because it:

- Enables the Tribe to mobilize the long-term support necessary for energy project development that extends beyond changing political administrations

- Helps address barriers to energy development by providing a long-term view that prioritizes projects over the next several decades

- Engages stakeholders from all segments of the community to help the Tribe pursue energy development projects in a thoughtful and strategic manner.

"The future of the Tribe resides within the imagination, ownership, and participation of its members and constituents," explained START team member Lesley Kabotie of the Crow Tribe. "Tribes work continuously to assemble the framework for healthy, self-sustaining economies that can support a viable and active community in every aspect."

\section{Key Steps to Success}

The Office of Indian Energy's strategic energy planning process is comprised of nine sequential steps based on experience in energy planning. Each step provides the foundation for maximum results as Tribes turn their vision into action. It is a natural progression of informed and achievable decision making. The process can be completed within months or potentially years, depending on drivers within a Tribe. This flexibility empowers Tribes to move forward at a pace that best suits their needs and resources.

Step 1: Identify and convene stakeholders. Anyone who generates, controls the sale of, sells, or uses electricity or gas is a critical stakeholder. By involving all stakeholders early in the planning stages, Tribes increase their chances of successful project development.

Step 2: Form a leadership team. It is important to choose a leadership team that has the power to make decisions, direct the funding resources, and promote the project throughout the process.

Step 3: Develop a common energy vision. Identifying top priorities can help develop a vision that will ensure a unified effort.
9 Measurement \&

Verification $(\mathrm{M} \& \mathrm{~V})$

and Plan Alterations

Energy Plan

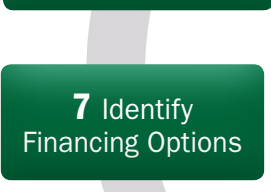

\section{Strategic Energy} Planning Process

3 Develop Energy Vision

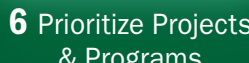
\& Programs

5 Develop Specific Goals

The nine-step process for community strategic energy planning. This process is a framework that can be modified to meet each community's need.

Step 4: Assess energy needs and resources. Understanding energy use at the local level helps clarify which programs and projects will best fit the needs of the community. Develop a community energy baseline to help design cost/benefit rankings for potential programs.

Step 5: Develop specific energy goals. These should be based on the community's vision and energy baseline.

Step 6: Prioritize projects and programs. Identify and evaluate supply-and-demand policy and program resource options and match these to the goals and program rankings.

Step 7: Identify financing options. Various options are available to finance energy projects, including federal, state, and non-profit grants and loans.

Step 8: Compile the energy plan. This includes objectives, goals, baseline, program options and surrounding analysis, and recommended options for policymakers.

Step 9: Measure and evaluate, modify plan. Is there a current plan for evaluation of programs? How high is the demand for a formal document or announcement? How will the results be communicated back to the individual program implementers? 


\section{Strategic Energy Planning in Action}

In 2012, START teams used this process to guide select communities in creating their own energy development plans.

\section{Contiguous United States}

In Arizona, the START team worked with both the Hualapai and Pascua Yaqui Tribes. The strategic energy planning session helped the Hualapai Tribe evaluate different solar options for its Grand Canyon West development. At Pascua Yaqui, the planning has resulted in project development strategies for a photovoltaic system at the Tribe's Casino Del Sol facility. In addition, the Tribe plans to partner with its utility to do energy planning outreach at community events as well as lobby its council to support energy planning efforts.

"I was really impressed with the whole [strategic energy planning] process," said Maria Arvayo, development services director for the Pascua Yaqui Tribe. "It made attendees feel very empowered-like we could really do something."

The idea of creating a vision for the Tribe's energy future is something that "resonates with the general public," she said. "It is an important part of our overall development."

In Wisconsin, the START team facilitated a strategic energy planning workshop for the Forest County Potawatomi Tribe that has helped tribal leadership and staff gain a shared understanding of the project development and operation aspects of a small-scale biomass technology, and take the next steps toward system procurement.

The START strategic energy planning workshop held at the Passamaquoddy Tribes of Indian Township and Pleasant Point in Maine has helped open the lines of communication between the two reservations that exist under a single Tribe.

Though Indian Township sought the support of START, former councilwoman and Tribe consultant Elizabeth Neptune said the participation of Pleasant Point leaders is critical as the Tribes pursue the development of a large wind project. The energy planning workshop provided the opportunity for both reservations to "come to the table and take an active part in energy project development," she said.

Neptune praised the START planning process for being "very concise and tribal specific."

"I've done a lot of planning, and this one seemed to fit better than any other one," she said. "I feel very positive about how well it worked to connect people." She especially liked that the process explored "where we came from," which she said "helped us refine our vision for renewable energy and figure out our next steps."

"It was a good reminder of all the challenges we have faced in the last 100 years, but that we've also overcome those barriers," Neptune said. "It demonstrated our resiliency and how we can tap into that resiliency to carry us another 100 years."

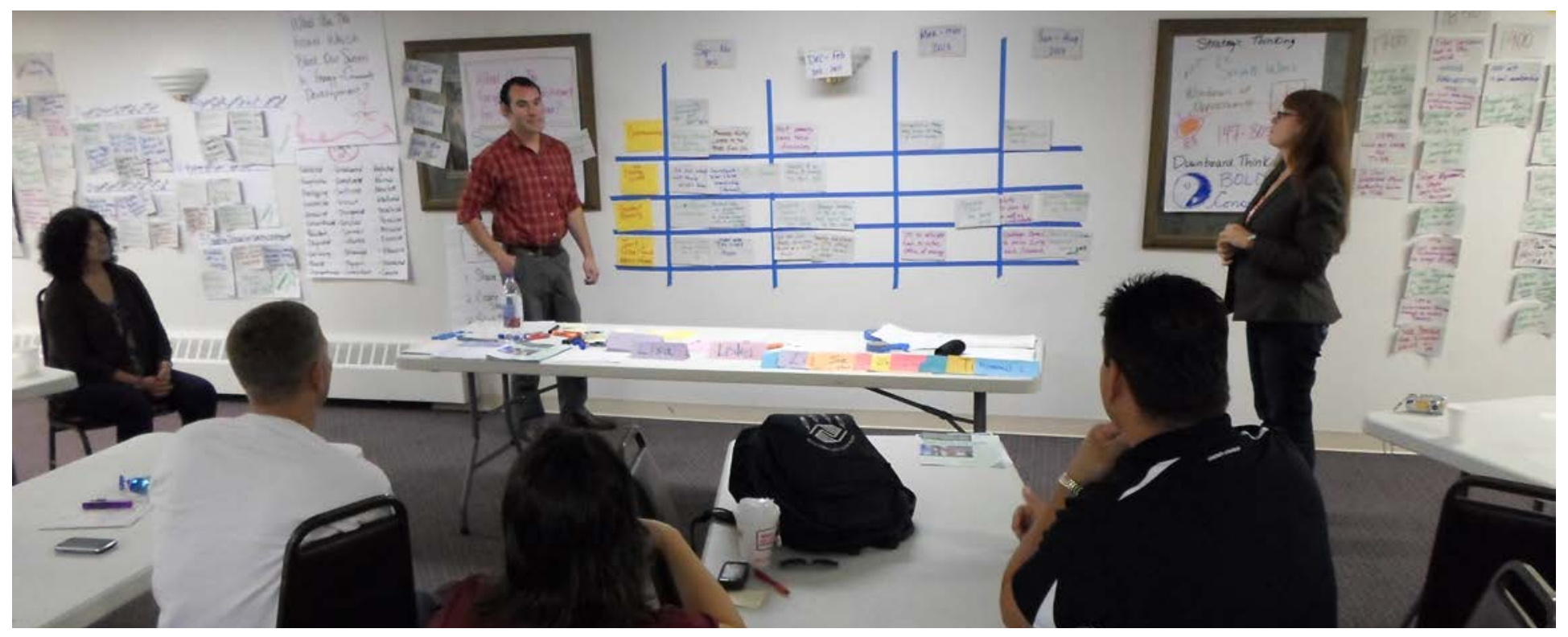

Engaging stakeholders and identifying priorities is critical to developing a strong energy vision. Here, the START workshop held at the Passamaquoddy Tribes of Indian Township and Pleasant Point in Maine helped open the lines of communication between two reservations that exist under a single Tribe. Photo by Paul Dearhouse, NREL 24503 


\section{Alaska}

All five selected 2012 START communities in Alaska- Arctic Village Council, Native Village of Kwinhagak, Native Village of Teller, Organized Village of Kake, and Venetie Village Councilwere engaged in strategic energy planning activities to prioritize projects, garner community support, and strengthen their ability to pursue grants.

"Energy planning is a valuable tool for communities looking to partner with state and federal agencies for grant opportunities," Dane said. "It is a cohesive approach to capture these opportunities."

For example, after participating in a START strategic energy planning workshop in late 2012, the Organized Village of Kake has applied for four grants and already received one for technical assistance.

Kake is only about 100 miles from Juneau, but because it sits on an island in the Gulf of Alaska, it shares challenges that more rural native communities have in accessing energy. The community of less than 600 residents struggles with out-migration, loss of employment, and high energy costs that can top $\$ 0.60$ per kilowatthour-six times higher than some neighboring communities, according to Gary Williams, executive director of Kake.

Stakeholders for the various entities that would be impacted by energy development in Kake participated in the workshop, including the electric utility co-op, tribal government, local and regional native corporations, and the housing authority.

"The planning process pulled information directly from our community members as well as our partners and gave them ownership of the end product," Williams said. "It has really helped focus our energy initiative to a fine tip. It has been phenomenal for our community."

START team member and senior project leader at NREL Dr. Brian Hirsch agreed. "We were able to get the right players around the room and incorporate their concerns," he said. By coordinating multiple stakeholders and securing their buy-in, Kake is in a stronger position to capture grant opportunities available at the state and federal level.

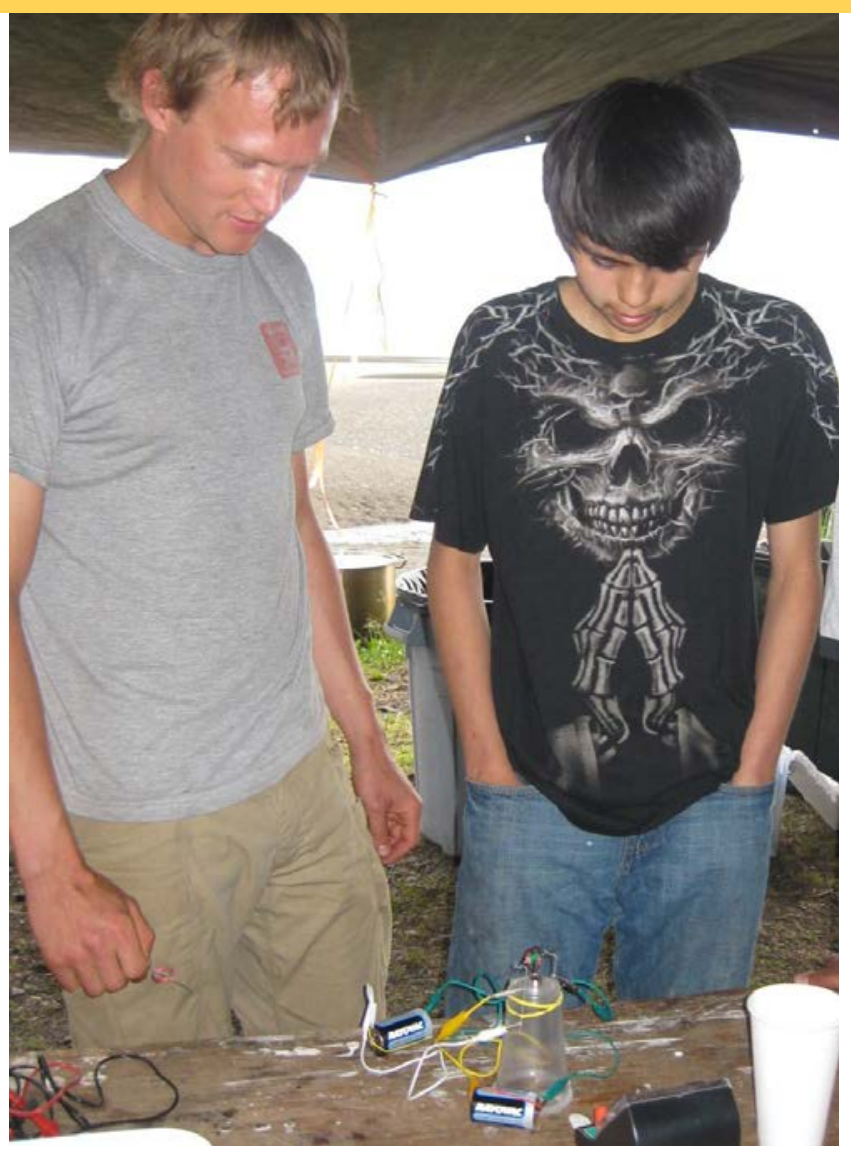

Strategic energy planning can help prioritize energy projects to build a sustainable community for future generations. Here, NREL's Levi Kilcher advises Skyler Copsey at the youth energy training in Kake, Alaska. Photo by Connie Fredenberg/Marsh Creek, NREL 22725

\section{Learn More}

To read more success stories in tribal energy development and access helpful resources for strategic energy planning and renewable energy project development, visit the DOE Office of Indian Energy Resource Library at $h t t p: / / w w w . e n e r g y . g o v / i n d i a n e n e r g y / r e s o u r c e s /$ energy-resource-library.

Learn more about the START Program at www.energy.gov/indianenergy/resources/start-program.

Front page photo by Dennis Schroeder, NREL 21010. Page 2 illustration by Dean Armstrong and Stacy Buchanan.

\section{Renewable Energy Curriculum and Technical Assistance for Tribes}

The DOE Office of Indian Energy offers a series of online educational courses specifically for tribal leaders and professionals. These free, on-demand webinars provide an overview of renewable energy technologies, strategic energy planning, and renewable energy project development and financing. Access the webinars at www.nterlearning.org (search for "Indian Energy").

Tribes can apply to receive up to 40 hours of free technical assistance from DOE to help with strategic energy planning. Apply online at energy.gov/indianenergy/technical-assistance. 